\title{
Helena Motoh
}

\section{Lobanje v muzeju? - medkulturni vidiki razprave o muzealizaciji človeških ostankov}

Kaj v slovenski prestolnici hkrati počno poltretje tisočletje star Egipčan, sto let star Ekvadorec in trije prav tako vsaj stoletni Tibetanci? Prav tako kot brez števila drugih prazgodovinskih, antičnih in poznejših posameznikov iz manj oddaljenih krajev - redkokdaj z imeni in najpogosteje brez njih - kratek izsek svoje večnosti preživljajo $\mathrm{v}$ vitrinah in depojih slovenskih muzejev. Kot večina drugih zgodovinskih, etnoloških in podobnih muzejev po Evropi tudi slovenske institucije te vrste v svojih zbirkah hranijo številne človeške ostanke, posmrtno telesno zapuščino posameznikov, ki so, namesto da bi bili še naprej pokopani v skladu z navado svojega časa in prostora, zdaj muzealizirani, spremenjeni v muzejske eksponate. Proces, ki ni imel čisto nič opraviti z voljo pokojnega posameznika, ampak s kompleksnim spletom različnih zgodovinskih okoliščin, je privedel do tega, da so se poleg celjskih grofov in množice anonimnih in napol identificiranih prebivalcev nekdanje Ljubljane $\mathrm{v}$ muzejih znašli tudi egipčanska mumija (Kajfež, 2014), južnoameriška posušena glava, t. i. čanca (Škerlj, 1953-1954), in tri lobanje, oblikovane v tradicionalne tibetanske izdelke. Statusu teh in drugih predmetov človeškega izvora v slovenskih muzejih je bil v znanstvenem kontekstu posvečen izčrpen zbornik prispevkov Etika $v$ muzejih - Ravnanje z ostanki živih organizmov (Kolar Osvald in Petruša Štrukelj, 2017), posebej dvema med njimi - čanci in jermenu iz človeške kože - pa tudi članek Alenke Bartulović in Dana Podjeda (Bartulović in Podjed, 2008).

Razstavljanje človeških ostankov, v obdelani ali neobdelani obliki, je vselej do neke mere kontroverzno početje. Mnogokrat je prav ta specifika zgodovinsko gledano prispevala $\mathrm{k}$ atraktivnosti in priljubljenosti teh predmetov v zbirateljskih krogih. Po drugi strani pa dejstvo, da pripadajo nekemu človeku, nekoč živemu posamezniku, te ostanke bistveno loči od drugih muzejskih predmetov in razstavljalce, pa tudi gledalce, postavlja pred številne etične dileme. Dodatno sporno je lastništvo teh predmetov, pa naj gre za egiptovske mumije ali pa južnoameriške čance, saj različne skupnosti ostanke zahtevajo nazaj $\mathrm{z}$ argumentom, da gre pri muzealiziranemu pokojnem posamezniku za enega »od njih«. Tematiko bolj ali manj uspešno naslavlja več mednarodnih standardov in dokumentov.

Pričujoči članek je nastal kot del raziskave v okviru dveh nacionalnih znanstvenih projektov. V okviru prvega smo se osredotočili na slovenske misijonarke v Indiji v 20.

DOI:10.4312/ars.14.2.165-178 
stoletju, v drugem pa na vzhodnoazijske zbirke v slovenskih muzejih. ${ }^{1}$ Oprijemljivo presečišče med obema predstavlja depo Slovenskega etnografskega muzeja, ki hrani tako zbirko medvojnega jezuitskega »indijskega muzeja« kot najobsežnejšo zbirko vzhodnoazijskih predmetov pri nas, ki jo je v začetku 20. stoletja s Kitajske v Slovenijo prinesel mornariški častnik Ivan Skušek ml. (Čeplak Mencin, 2012, 98-117). V obeh zbirkah lahko najdemo posamezne predmete religijskega značaja, ki so izdelani iz človeških ostankov, in dvema od njih bo v nadaljevanju posvečen članek. ${ }^{2}$ Predmeta iz zbirk Slovenskega etnografskega muzeja, ki ju bom posebej analizirala, sta iz lobanje narejena skleda (thod pa/kapāla), ki je del zbirke jezuitskega indijskega muzeja, in bobenček (damaru) iz dveh lobanj, ki je v muzej prišel kot del Skuškove zbirke. Oba v okviru zbirk, v kateri sta bila umeščena, predstavljata svojevrstni izjemi, ne le zaradi posebnosti materiala, iz katerega sta izdelana, pač pa tudi zato, ker sta tibetanskega oz. himalajskega izvora, matični zbirki pa sta sicer nastali drugje - v Bengaliji in Pekingu - in večinoma obsegata bengalske oz. kitajske predmete. Skleda thod pa je bila $\mathrm{v}$ tridesetih letih 20. stoletja kot del jezuitske zbirke postavljena na ogled v Indijskem muzeju v Ljubljani, vse od zaplembe po jezuitskem procesu l. 1949 (Nedavni proces proti ljubljanskim jezuitom, 1949) pa je bila spravljena sprva v skladiščih Federalnega zbirnega centra in naposled v Slovenskem etnografskem muzeju (Štrukelj, 1980/1982, 145). Boben damaru pa je bil sprva del zasebne Skuškove zbirke (I. inventarna knjiga muzeja Goričane, $229 \mathrm{MG}$ ), zdaj pa je del neevropske razstave v Slovenskem etnografskem muzeju.

Prav predmeti, kot sta skleda thod pa in boben damaru iz Slovenskega etnografskega muzeja, odpirajo še dodaten vidik razprave o muzealizaciji človeških ostankov, namreč, da morda vseh muzejskih predmetov, ki so človeškega izvora, ne gre spravljati pod skupni imenovalec. Pri iskanju standardov in načinov, kako te predmete predstaviti javnosti (ali jih umakniti oz. celo vrniti) prav tibetanski predmeti namreč zahtevajo dodaten premislek o samem odnosu do človeških ostankov. Etični in poklicni standardi, okrog katerih se je muzejska stroka ob soočenju s problematiko večinoma poenotila, namreč temeljijo na izrazito evropskem razumevanju pravilnega odnosa do človeških ostankov po smrti posameznika in vprašati se je mogoče, v kolikšni meri je ta pristop relevanten za tovrstne predmete iz drugih kultur.

Članek bo zato k problematiki muzealizacije človeških ostankov pristopil na več ravneh. $\mathrm{V}$ prvem delu bo predstavil primera dveh tibetanskih predmetov iz zbirk

1 Pričujoči prispevek je nastal v okviru projektov J6-8258, Slovenske misijonarke v Indiji: pozabljeno poglavje $v$ medkulturnih odnosih (2017-2020) in J7-9429, Vzhodno-azijske zbirke $v$ Sloveniji: Vpetost slovenskega prostora $v$ globalno izmenjavo predmetov in idej $z$ Vzhodno Azijo (2018-2021) ter programske skupine Azijski jeziki in kulture (P6-0243), ki jih iz državnega proračuna financira Javna agencija za raziskovalno dejavnost Republike Slovenije (ARRS).

2 Odnos drugih kultur do smrti in posmrtnega življenja je tudi sicer predstavljal pogost predmet fascinacije evropskih popotnikov in zbiralcev. Cf. npr. Vampelj Suhadolnik, 2019, 49-76 in Kang, 2019, 77-108. 
Slovenskega etnografskega muzeja in analiziral pomen tovrstnih predmetov v tibetanski tradicionalni družbi. Drugi razdelek bo posvečen specifiki zbiranja predmetov iz človeških ostankov ter problematiziral medkulturne vidike teh vprašanj na primeru tibetanskih predmetov, izdelanih iz človeških ostankov.

\section{Tibetanska predmeta iz lobanj v Slovenskem etnografskem muzeju}

Prvi od omenjenih dveh predmetov je skodela, izdelana iz lobanje, t. i. skleda thod pa (tib.) oziroma kapāla (skr.). Thod pa so v tibetanski tradiciji lahko zelo različne, skupno pa jim je, da so bodisi izdelane iz človeške lobanje ali pa želijo ustvariti videz, da so - tudi kadar so izdelane iz drugih, lažje dostopnih materialov (Fuentes, 2017). Lobanjske sklede so običajno izdelane v eni od dveh tipskih oblik. Pri prvi je uporabljena celotna lobanja, ki je umetelno izrezljana in/ali okrašena s kovinami, pogosto srebrom in dragimi ter poldragimi kamni. Pri taki obliki thod pa spodnji del s čeljustnico in obraznim delom tvori skledo, zgornji del lobanje pa pokrov. Drugi tip lobanjske sklede je narejen le iz odrezanega zgornjega polkrožnega dela lobanje in je brez pokrova. Ta preprostejši tip je lahko povsem neobdelan, lahko pa sta rob in notranjost prevlečena $\mathrm{s}$ srebrom in okrašena. Lobanjske sklede, sploh v bolj ornamentiranih inačicah, so pogosto umeščene na prav tako podrobno okrašen podstavek.

Lobanjske sklede imajo dolgo tradicijo obredne uporabe, ki je predvsem vezana na tantrične prakse, tako $\mathrm{v}$ hindujskih kot $\mathrm{v}$ budističnih inačicah. $\mathrm{V}$ hindujskih kontekstih kapāla predstavlja enega od pogostih atributov pri upodobitvah divjih, še posebej ženskih božanstev. Motiviko lobanjskih atributov sploh pogosto srečamo pri tantričnih boginjah iz skupine mahāvidyā, kamor sodijo npr. boginje Kali, Tara in Chinnamasta (Kinsley, 1997, 238 isl.). Boginja Kali je pogosto upodobljena z lobanjsko skledo kot atributom na levi strani telesa, pri čemer vanjo lovi kri, ki izteka iz pravkar odrezane glave, ki jo prav tako drži ena od rok na levi strani. Boginja Tara, ki je upodobljena na podobne načine kot Kali, prav tako pogosto v rokah drži lobanjsko skledo. Pri upodobitvah Chinnamaste pa sta skledi najpogosteje dve, držita pa ju pomočnici boginje in vanju lovita kri, ki brizga iz boginjine odrezane glave. Zanimivo je, da prav te tri boginje in njihove upodobitve tudi zaznamuje izrazita seksualna konotacija, za tantrične tradicije značilen preplet motivov smrti in seksualnosti. Še ena tantrična boginja, Camunda, povezana z boginjo Durgo, je prav tako pogosto prikazana s številnimi ornamenti, izdelanimi iz kosti ali lobanj ter okrasjem v obliki lobanj, med katerimi sta tudi lobanjska skleda in boben damaru (ibid.).

Lobanjske sklede so med indijskimi religijskimi šolami povezovali tudi z izginulo šivaistično sekto »kapalikov«, ki so ime dobili prav po tem, da so s seboj nosili takšne sklede. Zapisi o tej sekti, ki datirajo v 7. in 8. stoletje, pričajo o tem, da je bila uporaba 
človeških kosti le ena od tabuiziranih praks, ki so bile značilne za kapalike, mazali naj bi se tudi s človeškim pepelom in se predajali alkoholu, mamilom in orgiastični seksualnosti (Lorenzen, 2000, 81 in Lochtefeld, 2001, 348-349). David Lorenzen, ki je kapalike podrobno preučeval, umešča vse navedene prakse v tantrični kontekst. Za tantrična prepričanja naj bi bil namreč značilen radikalen monizem, s skrbno ritualiziranim izvajanjem prepovedanih praks naj bi torej simbolno poudarili enost vsega $\mathrm{v}$ vesoljstvu, iz katere ni izključeno še tako tabuizirano početje (ibid.).

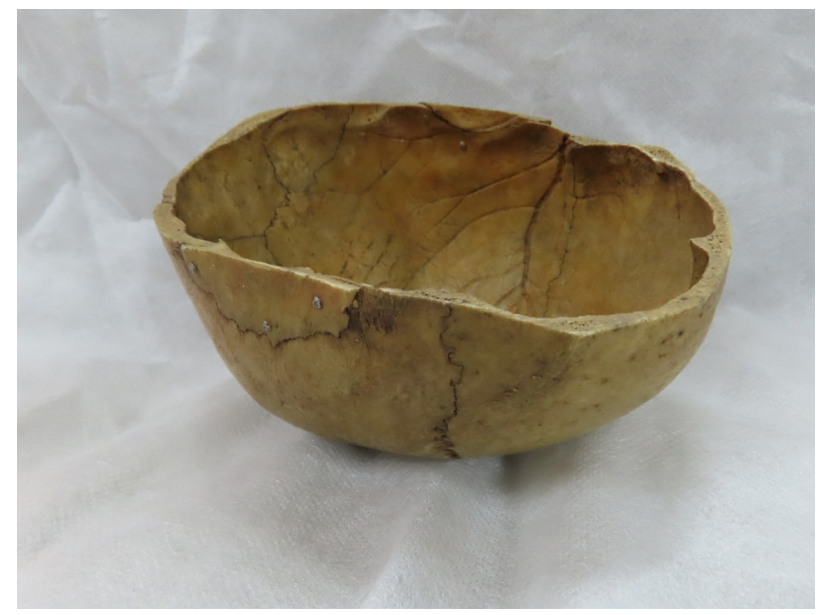

Slika 1: Lobanjska skleda (kapala) (foto: Helena Motoh/SEM).

V tibetanski tradiciji so lobanjske sklede prav tako povezane s tantričnimi praksami in verovanji, ki pa so v tem primeru umeščena v budistični kontekst. Kot že v hindujskih interpretacijah tantričnih verovanj je tudi v tibetanskih lobanjska skleda simbolno uporabljena za pijačo, hrano ali daritve, po verovanju pa lahko služi za najrazličnejše substance, vse od nektarja amrita, alkohola, obrednih kolačev torma pa do krvi, kostnega mozga, drobovja, mesa, src in pljuč. Simbolna vrednost dejanske lobanje, ki je uporabljena za kapalo, je v veliki meri odvisna od tega, komu je ta lobanja pripadala. Posebna moč se pripisuje lobanjam plemenitnikov, žrtev umorov, otrok ob prehodu $\mathrm{v}$ puberteto in otrok, ki so bili rojeni kot posledica incestuoznega odnosa. Kot indijska tantrična božanstva tudi tibetanska božanstva lobanjsko skledo nosijo v levi roki, pri čemer je skupaj z motivom ukrivljenega noža ali motivom vajre pogosta tudi aluzija na kri, ki se steka v skledo (Beer, 2003, 110-112). V tantričnem kontekstu lobanjska skleda thod pa skupaj z obrednim nožem pogosto nastopa med pripomočki, povezanimi s tantričnim ritualom chöd, »obredom rezanja«, kjer se izvajalec obreda simbolno odreže od svojega ega skozi dolgo vizualizacijo, kjer njegovo telo razkosajo in požrejo demoni. Asociacije na kosti in lobanje so značilen element vseh pripomočkov 
za chöd, poleg lobanjske sklede je to najbolj izrazito pri trobenti kangling, ki je narejena iz okrašene stegnenice, in pri bobenčku damaru, ki je narejen iz dveh staknjenih zgornjih delov lobanj. Za kangling so najbolj zaželene kosti šestnajstletnih deklic, pa tudi enako starih dečkov, zatem žrtev umorov in hudih nalezljivih bolezni (Beer, 2003, 110). Boben damaru, tretji obvezni ritualni predmet tantričnega obreda chöd, pa ima med vsemi omenjenimi najverjetneje najdaljšo tradicijo, saj so najstarejše upodobitve tako oblikovanih glasbil našli že med piktogrami harapske civilizacije. Kot pomemben simbol se ga povezuje z bogom Šivo. Dvodelni bobenček, po katerem med vrtenjem ročaja v obe smeri udarjata dve na vrvici privezani kroglici, je lahko zelo različnih velikosti, za chöd pa so danes običajno uporabljeni sorazmerno večji bobni damaru. Tudi en boben te večje vrste hrani Slovenski etnografski muzej kot del zbirke nekdanjega Indijskega muzeja. Bobni damaru so okrašeni s svilenim trakom v obliki trolistnih zavitih oblakov s petbarvnim volančkom. Posebna oblika damaru, kakršnega hrani tudi Slovenski etnografski muzej v okviru Skuškove zbirke, pa je bil tantrični damaru, t. i. kapalika damaru. Tovrstni bobni so bili tradicionalno izdelani iz dveh staknjenih lobanj petnajst ali šestnajst let starega dečka in deklice (včasih je bilo dekle tudi mlajše). Sozvočje staknjenih moške in ženske lobanje simbolizira seksualno združitev in za tantro značilno poudarjanje enotnosti dvojega, simbolno tudi enotnost metode in modrosti. Pri kapalika damaru so iz človeških kosti pogosto izdelane tudi kroglice in okras na ročaju (Beer, 2003, 107-110).

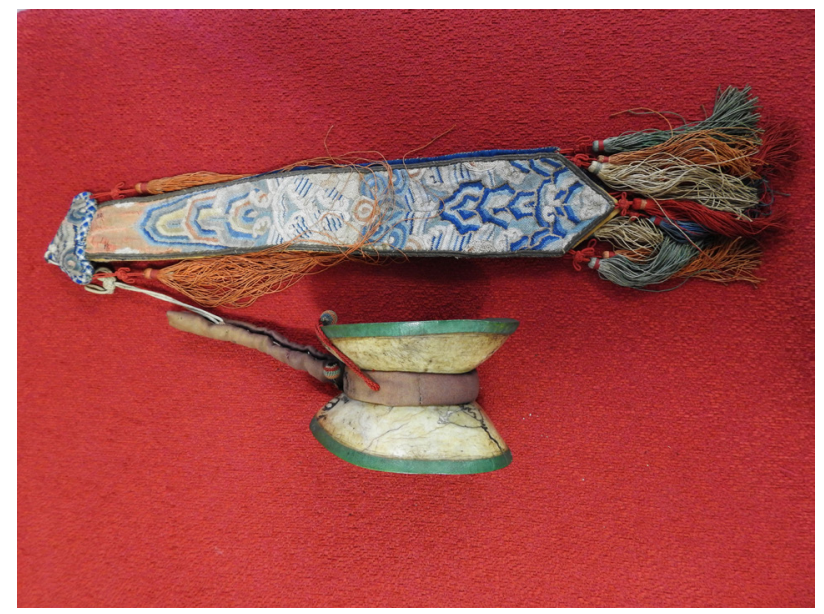

Slika 2: Boben iz para lobanj (kapalika damaru) (foto: SEM).

Očitno je torej, da predmeta iz lobanjskih kosti, ki ju hrani Slovenski etnografski muzej, tako lahko identificiramo kot kapalo, lobanjsko skledo, in kapalika damaru, boben iz para lobanj. Glede na to, da oba izvirata iz širše himalajske regije, je najbolj 
verjetno tudi, da sta oba povezana s tantrično tradicijo. Lobanjska skleda je v nakupni knjigi izvenevropskih predmetov iz l. 1965 (Nakupna knjiga izvenevropskih predmetov SEM) zavedena pod imenom »Obredna čaša - lobanja« in številko 37 kot del skupine 400 predmetov, za katere knjiga nakupov navaja, da so bili del »Jezuitske zbirke« (ibid.), ki jo je muzej dobil od Federalnega zbirnega centra. Poleg navedenega knjiga nakupov ponuja le malo dodatnih informacij, navaja prvotno inventarno številko (248) in v oklepaju dodaja »Tibetanci iz Sikkima«. Kljub fragmentarnosti pa je ta zapis zelo poveden. Jezuitsko zbirko za t. i. Indijski muzej, ki so ga 1. 1935 odprli pri cerkvi sv. Jožefa na Poljanah v Ljubljani (Motoh, 2020, 36 in Naš indijski misijonski muzej v Ljubljani, 1935, 44), so prispevali jezuiti, ki so v Bengalijo odšli 1. 1929 in skupaj s hrvaškimi jezuiti vodili misijon v kraju Basanti v odročnem področju v delti Gangesa, imenovanem 24 Parganas. Kasneje so svojo misijonarsko dejavnost razširili še na bližnji kraj Morapai (Kokalj, 1989, 47-53). Kot je mogoče razbrati iz misijonskega tiska, predvsem iz posebnega lista $\mathrm{z}$ naslovom Bengalski misijonar, ki je v tridesetih letih izhajal kot priloga Glasnika Srca Jezusovega, je bilo delo v teh skrajno revnih krajih težko tudi za misijonarje. Primanjkovalo je osnovnih dobrin, še posebej pa so življenje oteževale naravne nesreče, ki so jih nekajkrat prizadele, predvsem uničujoče poplave in požar. $\mathrm{V}$ teh razmerah je bil bengalski misijon povsem odvisen od pomoči in pridobivanju darov je bil namenjen tudi velik del misijonarske aktivnosti v stikih z domovino. Donacije so zbirali neposredno, s postavljanjem namenskih nabiralnikov, t. i. »bengalčkov«, kamor so lahko posamezniki vrgli svoj prispevek, pa tudi s pozivi v misijonskem tisku. Pomemben del

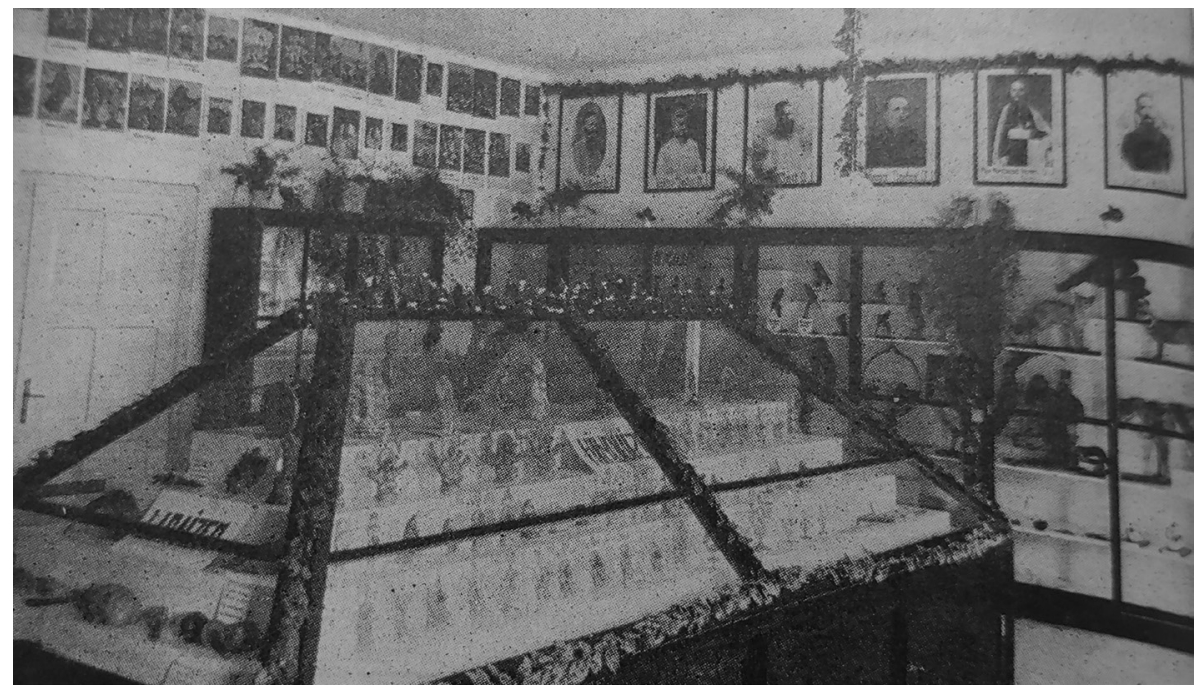

Slika 3: Indijski muzej (vir: Naš indijski misijonski muzej v Ljubljana, 1935). 
promocije bengalskega misijona je bil tudi t. i. »Indijski muzej«. Muzej so ob cerkvi sv. Jožefa na ljubljanskih Poljanah odprli 12. junija 1935. Zbirka Indijskega muzeja je bila izjemno raznolika. O predmetih in dekoraciji še danes priča ohranjeni del zbirke v Slovenskem etnografskem muzeju, obširno pa je o zbirki poročal tudi misijonski tisk tistega časa, ki omenja tudi več predmetov in eksponatov, ki danes niso več del zbirke oziroma so izgubljeni. Kot je bilo značilno za misijonske razstavne predstavitve tistega časa (Motoh, 2020, 36-37), je muzej vseboval dva tematska sklopa gradiva: prvega, ki je poročal o misijonarski aktivnosti in jo promoviral, in drugega, ki je poskušal domačemu obiskovalcu predstaviti Indijo, njene običaje, ljudi, umetnost, religijo, pa tudi floro in favno. Religijski predmeti so bili razporejeni glede na posamezne religije, pri čemer sta, kot lahko razberemo iz ohranjenih fotografij Indijskega muzeja, bili posamični kategoriji vsaj »lamaizem« in »hinduizem«.

V stranskem levem delu vitrine, ki jo prikazuje zgornja fotografija (slika 3), se na sredini spodnje vrste predmetov, zbranih pod napisom »lamaizem «, dobro vidi tudi lobanjska skleda, ki jo še danes hrani muzej. Lobanjsko skledo omenja tudi članek, ki so ga objavili v Bengalskem misijonarju (Naš Indijski misijonski muzej v Ljubljani, 1935, 44), našteje jo za »hinduističnimi maliki«:

Spredaj v omari so molitveni mlinčki, človeška lobanja za zbiranje milodarov in žara, kamor shranijo pepel, ko sežgejo mrliče. Poleg stoji zvonec in nad njo boben, ki ju rabijo hinduistični duhovniki pri bogoslužju in beračenju.

Četudi so jezuiti v muzeju predmete očitno bolj pravilno razdelili med »lamaistične« in »hinduistične«, se v članku delitev povsem pomeša in sta tako lobanjska skleda kot boben iz lamaističnega dela vitrine opisana kot hinduistična predmeta. Napako je mogoče pripisati (anonimnemu) piscu članka, ki religij Indije očitno ni dosti poznal. Jezuiti, ki so misijonarili v Bengaliji, so specifike teh religij zagotovo poznali precej bolje. V Kalkuti in na področju svojega misijona so spoznavali hindujske tradicije lokalnega prebivalstva, v goratem delu Bengalije pa tudi tibetanske budiste. Za ta srečanja je bilo še posebej pomembno jezuitsko središče v Kurseongu, kjer je bil kolegij, v katerem so nekateri od slovenskih jezuitov preživeli tudi dlje časa. Med prvo trojico jezuitskih misijonarjev je v himalajskem pogorju najdlje bival Janez Udovč, ki je delal v Kurseongu v letih 1932-1934, leta 1934 pa je bil premeščen v Jezuitski kolegij sv. Jožefa v bližnjem Darjeelingu, kjer je delal kot ekonom, kuhar, pomočnik pri misijonskem delu, znan pa je postal tudi kot strokovnjak za gojitev cvetja (Kokalj, 1989, 295). Udovč je v misijonski tisk prispeval tudi najobširnejše poročilo o himalajskem delu Bengalije, ki je izšlo v knjižici Izlet na Himalajo (Udovč, 1937). V besedilu knjižice se posebej posveti tudi Tibetancem in njihovi religiji ter podrobneje omenja značilnosti tibetanskega budizma, npr. vlogo dalajlame (ibid., 37-40), uporabo molilnih 
mlinčkov (ibid., 32) in "molitev om ma-ni pad-me hum« (ibid.). Podrobneje omenja tibetanski budistični samostan »Pamiongči« (Pemayangtse) v bližini Darjeelinga (ibid., 22). Zanimivo je, da v knjižici omeni tudi dva tipa tibetanskega pokopa: sežig trupel (za katerega pripomni, da je značilen za Sikkim) in pokop z izpostavitvijo ujedam (ki ga pripiše Tibetu):

Navadne lame pokopljejo na skupna pokopališča. Vse druge Tibetance in Tibetanke pa čaka konec, ki ni preveč privlačen. Najprej prežene najeti lama vse hudobne duhove iz kraja, kjer se vrši pogreb. Nato truplo prepustijo posebnemu lamu, da ga pripravi za nebo: mrliča razseka na majhne kosce. Orli so tedaj deležni dobrega obeda, kosti pa pospravijo psi, ki jih nalašč za ta posel vzdržujejo in postijo. (ibid., 44)

Čeprav so bili s podrobnostmi tibetanskih pogrebnih navad jezuiti bengalskega misijona očitno kar dobro seznanjeni, pa o lobanjski skledi, ki so jo očitno pridobili od »Tibetancev iz Sikkima", kot poroča inventarni zapis, v njihovih tekstih nisem uspela najti niti ene omembe. To vsekakor preseneča, saj je raba človeških kosti kot materiala za izdelavo obrednih predmetov značilnost, ki jo ob stiku s tibetansko kulturo, še posebej pa ob nakupu teh predmetov, verjetno ni bilo težko opaziti.

$\mathrm{V}$ primerjavi z jezuiti, katerih spisi in zbirka pričajo o živem in intenzivnem stiku s tibetansko kulturo, pa je Ivan Skušek ml., v čigar zbirko sodi drugi lobanjski predmet, že omenjeni bobenček kapalika damaru, do tibetanskih predmetov prišel v Pekingu. Peking je bil v 19. in začetku 20. stoletja za tujce pomemben vir informacij o sicer zaprtem Tibetu, saj je bil tibetanski budizem zaradi tesnih vezi med zadnjo cesarsko dinastijo Qing in Tibetom v prestolnici močno prisoten. V začetku 20. stoletja so bila v Pekingu štiri središča tibetanskega budizma: tempelj Yonghegong, tempelj Zhongzhengdian znotraj Prepovedanega mesta in Rumeni tempelj (Huangsi) ter Črni tempelj (Heisi) severno od mestnega obzidja (Greenwood, 2013, 157 in Pearce, 2014). Zanimivo je, da je prav prek Pekinga v Evropo prišla tudi prva kapala, ki pa so jo 1 . 1862 na Mednarodni razstavi v Londonu predstavili kot »Konfucijevo lobanjo« (Pearce, 2014). Zbiranje tibetanskih predmetov in širjenje informacij o tibetanski kulturi na splošno postane še posebej intenzivno po britanskem vojaškem vpadu v Tibet v letih 1903-1904 (Harris, 2012). Predmeti tibetanske tradicije in znanje o posebnostih tibetanske kulture in religije tedaj sistematično vstopijo najprej v britanske, nato pa tudi $\mathrm{v}$ druge muzeje po Evropi. Tudi po tej plati obsežna in kvalitetna Skuškova zbirka sledi modi svojega časa. Tibetanskih predmetov je v njej več, med drugim tudi izjemno kvalitetnih budističnih kipcev, bobenček pa je zaradi svoje neobičajnosti zbiratelju verjetno predstavljal še posebej zanimiv predmet. 


\section{Medkulturni in medreligijski vidiki}

Fascinacija zbirateljev s predmeti, ki so izdelani iz človeških ostankov, ${ }^{3}$ je rasla s popularizacijo tibetanskih zbirk. Predmeti, kot sta omenjena skleda kapala in boben kapalika damaru, pa tudi drugi tipični predmeti iz človeških kosti in lobanj, so bili v evropskih zbirkah s preloma stoletja pogosto uporabljeni kot otipljiva ilustracija sprevrženosti tibetanske veje budizma. ${ }^{4}$ Zanimivo je, da je ravno drastična motivika obreda chöd in marginalni status, ki so ga imeli izvajalci tega obreda, bistveno prispevala k podobi tibetanskega budizma kot šamanistične in vraževerne, celo diabolične religije. Hkrati pa so se ti predmeti vpenjali v tradicijo razstavljanja človeških ostankov iz neevropskih kultur, ki jo najbolje ponazarja zgodovina razstavljanja egiptovskih mumij v evropskih muzejih (Stienne, 2019). Po dveh stoletjih razstavljanja človeških ostankov je proti koncu 20. stoletja sprejemljivost te muzejske prakse postala predmet mednarodne debate. Srž te polemike je seveda povezana $\mathrm{z}$ dediščino kolonialnega obdobja. Že vse od 19. stoletja je dehumanizacija prebivalcev kolonij, še posebej skozi prizmo rasne teorije, ustvarjala okvir, $\mathrm{v}$ katerem je bilo človeške ostanke pripadnikov neevropskih ljudstev mogoče razstaviti kot "primerke«, z njimi povezane etnološke zbirke pa umestiti v naravoslovni kontekst, saj naj bi predstavljali socialnodarvinistično razumljeno evolucijo človeških družb ( $c f$. Strmčnik, 2017). Ta klasifikacija je temeljila na distanci, ki jo je vzpostavila domnevna rasna drugačnost in kulturna različnost, pa tudi dejstvo, da so predmeti prihajali iz prostorsko zelo oddaljenih delov sveta. Zanimivo pa je, da se je podoben razosebljujoč učinek ustvaril tudi, ko je bila distanca časovne narave. Tudi "primerki« arheoloških izkopavanj (in v to kategorijo nato sodijo tudi egiptovske mumije ${ }^{5}$ ) so bili depersonalizirani in so iz pokojnikov neke oddaljene kulture postali muzealizirani predmeti. Časovna in prostorska oddaljenost, pa tudi distanca, ki so jo ustvarila kolonialna razmerja moči, so tako omogočile, da so bile te pokojne osebe postavljene na ogled enako kot vsi drugi predmeti v muzeju, od nagačenih živali do porcelana. Že samo dejstvo, da je oseba, ki je nekoč imela identiteto, svoje življenje in samozavedanje, postavljena na ogled v muzejskem prostoru, vzbuja številne dvome in pomisleke (cf. npr. Knez, 2017). Pieteta, ki sicer v določeni družbi pritiče pokojnim, je v tem primeru postavljena v oklepaj, ti

3 Glede mehanizmov in logike fascinacije nad muzealijami iz človeških ostankov $c f$. Bartulović in Podjed, 2008, še posebej str. 27-29.

4 Primera iz Slovenskega etnografskega muzeja sta $\mathrm{v}$ tem pogledu delno netipična. Glede na to, da so kapalo pridobili sami jezuiti bengalskega misijona, je $\mathrm{v}$ tej luči morda nenavadno, da $\mathrm{v}$ njihovih besedilih, kjer sicer kritizirajo malikovalske prakse budistov, ne najdemo nobene omembe problematičnosti prakse uporabe človeških kosti za ritualne predmete. Tudi o bobenčku iz Skuškove zbirke ne najdemo nobenih tovrstnih zapisov.

5 Pri egiptovskih mumijah je vprašanje anonimnosti seveda bolj kompleksno, saj samo okrasje mumij običajno razodeva tudi ime pokojnika, tako da je v dobesednem smislu težko govoriti o anonimnosti ostankov. Razen posamičnih bolje znanih posameznikov, katerih mumije so razstavljene v velikih svetovnih muzejih, pa so osebe, katerih mumije polnijo egiptovske zbirke evropskih in svetovnih muzejev, v zgodovinskem smislu večinoma pozabljene in njihova imena ne predstavljajo bistvene informacije, ki bi prispevala k personalizaciji njihovih posmrtnih ostankov. 
pokojni niso pokopani, običajno niso niti identificirani, muzealizirana predstavitev pa jim izkazuje le toliko spoštovanja kot vsem drugim muzejskim eksponatom. Poleg teh pomislekov pa muzealizirani človeški ostanki sprožajo tudi polemiko o tem, ali imajo muzeji sploh pravico, da si te pokojne lastijo. Ta debata je še posebej aktualna v postkolonialnem kontekstu, kjer so v zadnjih desetletjih številne domorodne skupine v Veliki Britaniji, ZDA in Avstraliji zahtevale, naj se pokojni muzealizirani posamezniki »vrnejo « v svojo skupnost (Petrović-Šteger, 2013). To logiko je seveda lažje zagovarjati v primeru tradicionalnih prostorsko zamejenih majhnih skupnosti, medtem ko časovna distanca in kompleksna politična zgodovina marsikdaj onemogočata jasen odgovor na vprašanje, kateri današnji skupnosti omenjena oseba pripada.

Sistemski odgovor na debate o muzealizaciji človeških ostankov je bila vrsta pravilnikov, konvencij in drugih programskih dokumentov, ki so v zadnjih desetletjih na to temo nastajali tako na nacionalni kot na mednarodni ravni. Med ključnimi mednarodnimi standardi, ki danes urejajo to področje, je treba omeniti deklaracijo UNDRIP in etična vodila zveze ICOM. Deklaracija Združenih narodov o pravicah staroselskih ljudstev (UNDRIP, 2007) določa pravico do repatriacije človeških ostankov (UNDRIP, 12. člen). Etični standardi združenja ICOM (Icomov kodeks muzejske etike, in natančneje, Icomov kodeks etike za naravoslovne muzeje) pa razvijajo tudi bolj kompleksen pristop do vprašanja razstavljanja in upravljanja s človeškimi ostanki v muzejskem kontekstu. Muzeji naj bi tovrstno gradivo namreč zbirali le, če ga lahko hranijo varno in spoštljivo (ICOM Code of Ethics, 3.7.), ter naj bi način predstavitve usklajevali s prepričanji skupnosti, iz katere izvirajo, kadar je ta znana (ICOM Code of Ethics, 2.5 in ICOM Code of Ethics for Natural History Museums, 1, A-E).

Na prvi pogled ICOM-ova kodeksa seveda predstavljata pomemben odmik od kolonialnega in z njim povezanega rasističnega diskurza, ki je neevropske oz. nebelske človeške ostanke obravnaval, kot da ne pripadajo nekdaj živim posameznikom, ampak kot muzejske predmete, izpostavljene na milost in nemilost pogledom kuratorjev, raziskovalcev in obiskovalcev. Vendarle pa je medkulturna občutljivost omejena na dolžnost muzeja, da se posvetuje z nosilci te iste kulture, oziroma s skupnostjo, kateri predmeti pripadajo. Brez večjih težav je mogoče ugotoviti, da je ravno ta atribucija v praksi največkrat nemogoča, sploh za starejše predmete in za predmete večjih kulturnih skupnosti. Kot že omenjeno, sta tako obravnavana lobanjska predmeta iz Slovenskega etnografskega muzeja po svojem izvoru precej nedvomno tibetanska, ampak o tibetanski kulturi ali skupnosti, ki naj bi bila njen nosilec, še zdaleč ne moremo govoriti enoznačno. Še več, kot opozarja Ayesha Fuentes, imajo skupnosti pogosto raznolike prakse in ne moremo pričakovati, da bi na ta način lahko pridobili primeren in enostaven odgovor, kako s predmetom iz človeških ostankom ravnati. To sama ponazori s primerom lobanjskih skled, za katere je med terenskim delom v tibetanskih skupnostih zasledila številne različne načine rokovanja in spoštljivosti: „videla sem, kako so jih prijemali s 
svilenimi šali, jih uporabljali za zbiranje prispevkov ali pa vanje točili žganje« (Fuentes, 2018, 8). Poleg tega pa A. Fuentes opozori še na kompleksnejši vidik te problematike. Vpogled v to, da so človeški ostanki kulturno občutljivo muzejsko gradivo, je namreč šele polovica celotne zgodbe. Predpostavka tovrstnih etičnih določil je, da so vsi človeški ostanki kulturno občutljivi na enak način (ibid., 7), ta način pa je seveda neposredno izpeljan iz pietetnih zapovedi evro-ameriškega, s krščanstvom zaznamovanega kulturnega konteksta. Če torej sledimo pomislekom A. Fuentes, bi dejanska medkulturna senzibilnost ne vključevala le formalne dolžnosti posvetovanja s skupnostjo, ki je simbolni »dedič« ostankov pokojnika, ampak bi morala prevprašati samo razumevanje statusa človeških ostankov v različnih kulturah. Če namreč razumemo ostanke pokojnika kot neke vrste lastnino njegovih potomcev, v biološkem ali simbolnem smislu, potem določila ICOM-ovih kodeksov dosledno priznavajo in upoštevajo to povezavo. Kaj pa če ostanki pokojnika v določeni kulturi niso razumljeni kot last njegove družine, temveč igrajo v kulturnih vzorcih te kulture povsem drugačno, celo ravno nasprotno vlogo? Različni religijski pogledi na telo, na njegovo minljivost, na smrt in posmrtnost $s$ seboj prinašajo tudi povsem različne ontologije, $v$ katerih je bivanjski - in s tem vrednostni - status telesa, trupla in posmrtnih ostankov zelo različen.

$\mathrm{V}$ tej luči so tibetanski lobanjski predmeti še posebej zanimivi, saj se vpenjajo v kompleksno idejno ozadje tibetanskega budizma in odpirajo povsem drugačen pogled na kulturno vlogo človeških ostankov. Četudi so za budizem značilne tudi prakse čaščenja relikvij in drugih vrst posvetitev posameznikovih ostankov, pa je pomemben element nauka tibetanskega budizma tudi vzpostavljanje distance do telesne identitete posameznika, kar morda še najbolj nazorno kažejo pogrebni rituali, o katerih je bilo govora prej, naj si gre za pokop z ujedami, raztros v reko ali sežig. Telo posameznika ob smrti ni več nekaj, kar bi temu posamezniku pripadalo. V tantrično obarvanih kontekstih pa gre tovrstno razumevanje še korak dlje, kar ponazarja ritualna raba lobanj in kosti, ki jo zasledimo pri izdelavi predmetov, kot so lobanjska skleda, trobenta iz stegnenice in lobanjski boben. Ločitev od lastne identitete, navezanosti na posamičnost bivanja, je namreč v sami srži rituala chöd, za katerega se ti predmeti uporabljajo. ${ }^{6}$ Anonimnost lobanj, odsotnost posamezne identitete človeka, čigar ostanki to so, hkrati pa to, da se lahko z njimi bistveno identificira vsak še živeči posameznik, je ključen del sporočila, ki ga nosijo ti predmeti. Idejo lastnine človeških ostankov v primeru tibetanskih lobanjskih predmetov tako nadomešča zavest o temeljni razlaščenosti, minljivosti in prehodnosti bivajočega posameznika. S tem se tibetanski predmeti iz človeških ostankov v temelju ločijo od razstavljenih »ekshumiranih « posameznikov, pa naj si gre za prazgodovinska okostja ali egiptovske mumije. Pri teh muzealizacija prekinja načrtovani način »bivanja« posameznika po njegovi telesni smrti. V primeru 
tibetanskih predmetov iz človeških ostankov pa je vsebina in pomen teh predmetov prav v diskontinuiteti z bivanjem posameznika - celo tedaj, kadar se posameznik odloči po smrti darovati svoje telo $\mathrm{v}$ ta namen. Tip predmetov, kakršna sta lobanjska predmeta iz Slovenskega etnografskega muzeja, tako ponuja možnost premisleka o kompleksnosti kodifikacije ravnanja s človeškimi ostanki in kaže, da je pravno kategorijo lastništva in etično kategorijo pietete treba dopolniti tudi z ontološkimi in religijskimi vidiki.

\section{Bibliografija}

Bartulović, A. in Podjed, D., Razstavljeno telo, Glasnik slovenskega etnografskega društva, 48, 2008 (št. 1, 2), str. 24-34.

Beer, R., The handbook of Tibetan Buddhist symbols, Chicago, London 2003.

Čeplak Mencin, R., V deželi nebesnega zmaja, 350 let stikov s Kitajsko, Založba /*cf., Ljubljana 2012.

Fuentes, A., An opinion piece regarding human remains, objects and ethics in cultural institutions, Theory, History, and Ethics of Conservation Working Group Newsletter, št. 22, 2018, str. 7-9.

Fuentes, A., Interpreting human remains in Tibetan ritual objects, Material Religion, 13, 2017 (3), str. 397-398.

Greenwood, K. R. E., Yonghegong: Imperial universalism and the art and architecture of Beijing's »Lama Temple» (disertacija), University of Kansas 2013.

Harris, C. E., The museum on the roof of the world: Art, politics, and the representation of Tibet, Chicago, London 2012.

I. inventarna knjiga muzeja Goričane od št. 1 MG-387 MG. Ljubljana, 1966-82.

ICOM Code of ethics for museums, 2017, https://icom.museum/wp-content/uploads/2018/07/ ICOM-code-En-web.pdf [20. 11. 2020].

ICOM Code of ethics for natural history museums, 2013, https://icom.museum/wp-content/ uploads/2018/07/nathcode_ethics_en.pdf [20.11.2020].

Kajfež, T. in drugi, Mumija in krokodil. Slovenci odkrivamo dežele ob Nilu. Katalog razstave, Ljubljana 2014.

Kang, B. Y., A death in the photo, Poligrafi 24 (93/94), 2019, str. 49-75.

Kinsley, D. R., Tantric visions of the divine feminine: The ten Mahāvidyās, Berkeley, Los Angeles, London 1997.

Kokalj, J., Pogovori ob Gangesu, Ljubljana 1989.

Kolar Osvald, D., in Petruša Štrukelj, E., ur., Etika v muzejih - Ravnanje z ostanki živih organizmov, Radovljica in Ljubljana 2017.

Knez, D., Trapist, žara in srce - Razstaviti ali ne?, v: Etika v muzejih - Ravnanje z ostanki živih organizmov (ur. Kolar Osvald, D., in Petruša Štrukelj, E.), Radovljica in Ljubljana 2017, str. 58-67.

Lochtefeld, J. G., The illustrated encyclopedia of Hinduism, Volume 1, New York 2001.

Lorenzen, D., A parody of the kapalikas in the Mattavilasa, v: Tantra in practice (ur. Gordon White, D.), Princeton, 2000, str. 81-96. 
Motoh, H., Azija med tigri in maliki - misijonske razstave v Sloveniji v prvi polovici 20. stoletja, Glasnik slovenskega etnografskega društva, 60, 2020 (št. 1), str. 34-40.

Nakupna knjiga izvenevropskih predmetov SEM, 1965.

Naš indijski misijonski muzej v Ljubljani, I. del., Bengalski misijonar, Priloga Glasnika srca Jezusovega 3/11, 1935.

Nedavni proces proti ljubljanskim jezuitom, Slovenski poročevalec, letnik 10, številka 102, 4. 5. 1949.

Pearce, N., From relic to relic - A brief history of the skull of Confucius, Journal of the History of Collections, Vol. 26, 2, julij 2014, str. 207-222.

Petrović-Šteger, M., Claiming the Aboriginal body in Tasmania. An anthropological study of repatriation and redress, Ljubljana 2013.

Stienne, A., To turn round a dead: Engagements with Egyptian mummies in London at the turn of the nineteenth century, Papers from the Institute of Archaeology, 2019, 28(1), str. 1-28.

Strmčnik, M., O etičnosti razstavljanja človeških teles in repatriaciji: Primer El Negra, v ur. Kolar Osvald, D., in Petruša Štrukelj, E.), Radovljica in Ljubljana 2017, str. 77-87.

Škerlj, B., Čanca v zbirkah ljubljanskega etnografskega muzeja, Slovenski etnograf 23-24, 19531954, str. 147-156.

Štrukelj, P., Neevropske zbirke v Muzeju Goričane, Slovenski etnograf, 31, 1980/1982, str. 145.

Udovč, J., Izlet na Himalajo, Indijska knjižnica, zv. 5, 1. 1937.

Ule, A., The Concept of Self in Buddhism and Brahmanism: Some Remarks, Asian Studies Vol. 4, Nr. 1, 2016, str. 81-95.

UNDRIP (United Nations declaration on the rights of indigenous peoples), 2007, https://www. un.org/development/desa/indigenouspeoples/declaration-on-the-rights-of-indigenous-peoples.html [20.11.2020]

Vampelj Suhadolnik, N., Death in Beijing, Poligrafi 24 (93/94), 2019, str. 49-75.

Helena Motoh

\section{Lobanje v muzeju? - medkulturni vidiki razprave o muzealizaciji človeških ostankov}

Ključne besede: Kapala, damaru, Tibet, človeški ostanki, muzealizacija

Članek se ukvarja s problematiki muzealizacije človeških ostankov na primeru dveh tibetanskih predmetov iz zbirk Slovenskega etnografskega muzeja, iz lobanje narejena skleda (thod pa/kapāla), ki je bila del zbirke jezuitskega Indijskega muzeja, in bobenček (damaru) iz dveh lobanj, ki je v muzej prišel kot del Skuškove zbirke. V prvem delu bo članek analiziral zgodovino teh dveh eksponatov in pomen tovrstnih predmetov v tibetanski tradicionalni družbi. Drugi del članka bo posvečen problematiki zbiranja in razstavljanja predmetov iz človeških ostankov in medkulturnim vidikom teh vprašanj na primeru tibetanskih predmetov, izdelanih iz človeških ostankov. 
Helena Motoh

\title{
Skulls in a museum? Intercultural aspects of the debate on the museification of human remains
}

\author{
Keywords: Kapala, damaru, Tibet, human remains, museification
}

The paper examines the issue of the museification of human remains, focusing on a case study of two Tibetan objects from the collection of the Slovenian Ethnographic Museum: a skullcup (thod pa/kapāla) that used to belong to the collection of the Jesuit Indian Museum, and a double-skull-drum (damaru) which came to the museum as part of the Skušek collection. In the first part the paper analyses the history of these two objects and their significance in traditional Tibetan society. The second part of the paper focuses on the collecting and exhibiting of objects made of human remains, and examines the intercultural aspects of these issues using the example of Tibetan objects made of human remains.

\section{O avtorici}

Dr. Helena Motoh je univ. dipl. filozofinja in sinologinja ter doktorica filozofije. Je višja znanstvena sodelavka pri Znanstveno-raziskovalnem središču Koper in docentka na Oddelku za azijske študije Filozofske fakultete Univerze v Ljubljani. Raziskovalno se ukvarja z evroazijskimi stiki, medkulturno filozofijo ter zgodovino azijskih misijonov in zbirk azijskih predmetov $\mathrm{v}$ Evropi. Je članica projektne skupine Vzhodnoazijske zbirke v Sloveniji (ARRS).

\section{About the author}

Helena Motoh has a BA in philosophy and sinology and a $\mathrm{PhD}$ in philosophy. She is a senior research fellow at the Science and Research Centre Koper and an Assistant Professor at the Department for Asian Studies, Faculty of Arts, University of Ljubljana. Her research focuses on Euro-Asian contacts, intercultural philosophy, the history of Asian missions and collections of Asian objects in Europe. She is a member of the research team of the national research project East Asian Collections in Slovenia. 